NASA Technical Memorandum 106592

AIAA 94-2627

99000

$p, 13$

\title{
Combined Contamination and Space Environmental Effects on Solar Cells and Thermal Control Surfaces
}

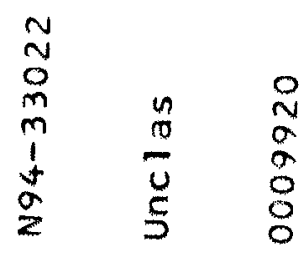

Joyce A. Dever

Lewis Research Center

Cleveland, Ohio

Eric J. Bruckner

Cleveland State University

Cleveland, Ohio

and

David A. Scheiman and Curtis R. Stidham NYMA, Inc.

Engineering Services Division

Brook Park, Ohio

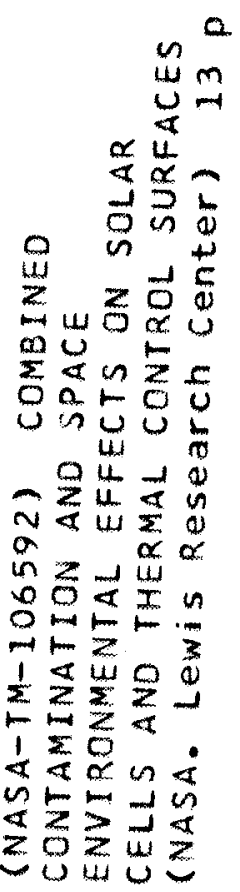

Prepared for the

18th AIAA Aerospace Ground Testing Conference

sponsored by the American Institute of Aeronautics and Astronautics Colorado Springs, Colorado, June 20-23, 1994

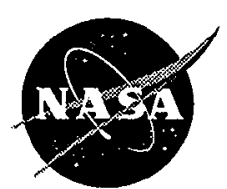

National Aeronautics and Space Administration 


\title{
COMBINED CONTAMINATION AND SPACE ENVIRONMENTAL EFFECTS ON SOLAR CELLS AND THERMAL CONTROL SURFACES
}

\author{
Joyce A. Dever* \\ NASA Lewis Research Center \\ Cleveland, Ohio \\ Eric J. Bruckner \\ Cleveland State University \\ Cleveland, Ohio \\ David A. Scheiman and Curtis R. Stidham \\ NYMA, Inc. \\ Brook Park, Ohio
}

\section{ABSTRACT}

For spacecraft in low Earth orbit (LEO), contamination can occur from thruster fuel, sputter contamination products and from products of silicone degradation. This paper describes laboratory testing in which solar cell materials and thermal control surfaces were exposed to simulated spacecraft environmental effects including contamination, atomic oxygen, ultraviolet radiation and thermal cycling. The objective of these experiments was to determine how the interaction of the natural LEO environmental effects with contaminated spacecraft surfaces impacts the performance of these materials. Optical properties of samples were measured and solar cell performance data was obtained. In general, exposure to contamination by thruster fuel resulted in degradation of solar absorptance for fused silica and various thermal control surfaces and degradation of solar cell performance. Fused silica samples which were subsequently exposed to an atomic oxygen/vacuum ultraviolet radiation environment showed reversal of this degradation. These results imply that solar cells and thermal control surfaces which are susceptible to thruster fuel contamination and which also receive atomic oxygen exposure may not undergo significant performance degradation. Materials which were exposed to only vacuum ultraviolet radiation subsequent to contamination showed, slight additional degradation in solar absorptance.

\section{INTRODUCTION}

In order to predict the long-term performance of solar cells and passive thermal control surfaces on low Earth orbit (LEO) missions such as the Space Station, it is necessary to know how optical properties of such materials will change during on-orbit exposure. The on-orbit environment includes the natural space environment, the induced external environment and spacecraft self-contamination effects. In LEO, spacecraft surfaces will be exposed to atomic oxygen, solar radiation and temperature cycling in a vacuum environment. Products of incomplete combustion of Space Shuttle thruster fuel are condensible and could contaminate nearby surfaces impinged upon by the thruster plume. $1,2,3,4,5,6$ Such contaminants are considered part of the external induced environment. Sputter contamination products and contaminants resulting from silicone degradation are considered self-contamination effects. On Space Station, surfaces that are at a negative potential relative to the plasma environment of space will attract positively charged ionized gases resulting in sputtering of those surfaces, if the potential differences are sufficiently high.? Products of this sputtering can deposit onto nearby surfaces. It is possible that the anodized aluminum truss of Space Station will undergo sputtering resulting in aluminum deposition onto the solar arrays which then oxidizes to form aluminum oxide. Silicones used on spacecraft include adhesives for solar cells and coatings for solar array blankets. Outgassing products of silicones in LEO may cause contamination of

\footnotetext{
* Member AIAA
}

Copyright 01994 by the American Institute of Aeronautics and Astronautics, Inc. No copyright is asserted in the United States under Title 17, U.S. Code. The U.S. Government has a royalty-free license to exercise all rights under the copyright claimed herein for Governmental purposes. All other rights are reserved by the copyright owner. 
nearby surfaces. ${ }^{89,10,11}$ Even for silicone materials which have passed outgassing requirements for a LEO mission, such outgassing products may be released upon atomic oxygen attack of the silicone surface.

It is necessary to understand how the natural LEO environmental constituents such as ultraviolet radiation, temperature cycling and atomic oxygen react with contaminated surfaces. This paper describes laboratory testing which was done to determine the combined effects of contaminants and the natural LEO environment on the performance of solar cells and thermal control surfaces.

\section{EXPERIMENTAL}

Materials Evaluated

Three sample trays were prepared for exposure to thruster fuel contamination. Table I describes the contents of these trays. They are shown in figure 1. As shown in the table, five fused silica disks were contaminated with silicone prior to thruster exposure. McDonnell Douglas Aerospace deposited $1200 \pm 120$ $\dot{A}$ of Dow Corning DC 200 (dimethylsiloxane) fluid onto these samples.

Z-93-P is a white thermal control paint consisting of zinc oxide pigment in a potassium silicate binder. Illinois Institute of Technology Research Institute (IITRI) prepared six samples containing the Z-93-P coating on aluminum alloy 6061-T6. McDonnell Douglas Aerospace prepared one sample of each of the following types of anodized aluminum materials: chromic acid anodized aluminum alloy 2219-T851, sulfuric acid anodized aluminum alloy 2219-T851 and MDA-proprietary High Emittance Duranodic ${ }^{\mathrm{TM}}$ Black (HEDB) anodize on alclad aluminum alloy 7075-T6.

Two $8 \mathrm{~cm}$ by $8 \mathrm{~cm}$ solar cells with cover glass of the type to be used on the Space Station were obtained from Spectrolab, Inc. These were deposited with $835 \pm 68 \dot{A}$ of aluminum oxide $\left(\mathrm{Al}_{2} \mathrm{O}_{3}\right)$ using electron beam evaporation prior to installation on Tray 3 for thruster fuel contamination.

\section{Sample Characterization}

Spectral transmittance and reflectance between 250 and $2500 \mathrm{~nm}$ were obtained using a Perkin Elmer Lambda- 9 spectrophotometer equipped with a $60 \mathrm{~mm}$ diameter integrating sphere. These data were used to calculate solar absorptance $\left(\alpha_{s}\right)$ of samples. The solar transmittance $\left(\tau_{s}\right)$ and solar reflectance $\left(\rho_{s}\right)$ values can be represented by equations (1) and (2) where $\tau(\lambda)$ and $\rho(\lambda)$ represent spectral transmittance and reflectance values, respectively, and $E(\lambda)$ represents solar spectral irradiance. For transparent samples, solar absorptance was calculated by equation
(3), and for opaque samples, solar absorptance was calculated using equation (4).

$$
\begin{aligned}
& \tau_{s}=\frac{\int_{250 \mathrm{~mm}}^{2500 \mathrm{~mm}} \tau(\lambda) E(\lambda) d \lambda}{\int_{250 \mathrm{~mm}}^{2500 \mathrm{~mm}} E(\lambda) d \lambda} \\
& p_{s}=\frac{\int_{250 \mathrm{~nm}}^{2500 \mathrm{~mm}} \rho(\lambda) E(\lambda) d \lambda}{\int_{250 \mathrm{~mm} m}^{255(\lambda) d \lambda}}
\end{aligned}
$$

$$
\begin{gathered}
\alpha_{s}=1-\left(\tau_{s}+\rho_{s}\right) \\
\alpha_{s}=1-\rho_{s}
\end{gathered}
$$

The accuracy in the measurement of $\alpha_{s}$ with the Lambda-9 instrument is expected to be approximately \pm .02 . The significant error in accuracy is attributed to the small size of the integrating sphere. The repeatability is expected to be approximately \pm .005 .

For opaque samples, room temperature total normal emittance $\left(\epsilon_{\mathrm{n}}\right)$ between 5 and $25 \mu \mathrm{m}$ was measured with a Gier Dunkle DB-100 Infrared Reflectometer. The repeatability in measurements with this instrument is expected to be \pm .005 . To minimize errors in accuracy, a high emittance and a low emittance standard are used to calibrate the instrument prior to each measurement.

Stainless steel witness coupons were weighed before and after thruster exposure to determine the extent of contamination. In order to identify the types of deposited contaminants, one of these witness coupons was studied with micro-Fourier Transformed Infrared ( $\mu$-FTIR) Spectroscopy using a Nic-Plan FTIR Microscope. The analysis was done using a $15 \mathrm{X}$ cassegranian objective over an area $100 \mu \mathrm{m}$ in diameter in the center of the sample.

Solar cell air mass zero (AM0) efficiency was obtained by measuring current-voltage, or IV, characteristics while the cell was under illumination. These measurements were made using separate current and voltage leads (four-wire) and obtaining voltage directly off the cell and obtaining current across a shunt resistor. The cell was biased at various voltages using a DC power supply. Illumination was provided by a Spectrolab X-25 (xenon arc) solar simulator with filtering to approximate the AM0 solar spectrum. A monitor solar cell was used to correct cell current for variations in light intensity which typically varies by a maximum of 1 - $2 \%$. Efficiency was calculated using an AM0 standard of 136.7 $\mathrm{mW} / \mathrm{cm}^{2}$. 


\section{Contamination Exposure}

The three sample trays were exposed in the Space Shuttle Primary Reaction Control System (PRCS) thruster facility (Test Cell 405) at NASA White Sands Test Facility in White Sands, New Mexico. The PRCS bipropellant thruster uses monomethylhydrazine (MMH) fuel and a nitrogen tetroxide $\left(\mathrm{N}_{2} \mathrm{O}_{4}\right)$ oxidizer. Samples were exposed in the test cell at a region near the outer edge of the exhaust plume, for up to three increments of 30.6 seconds of thruster-on time, during pulsed firing operation. Figure 2 shows the configuration of the sample trays with respect to the thruster. Figure $2 \mathrm{a}$ is a photograph of the three samples trays in the thruster facility. As can be seen in figure $2 b$ ( $a$ top view drawing of the test cell), the trays were mounted near the diffuser at an angle of approximately 30 degrees to the centerline of the thruster. The diffuser, pumped by a gaseous nitrogen ejection system, is used to expel the thruster exhaust from the test cell. Because the diameter of the plume at the front surface of the diffuser is larger than the diameter of the diffuser inlet, and since the diffuser surfaces are painted, a stainless steel shield was placed between the diffuser and the sample trays in order to prevent paint particles and debris from being blown back onto the sample trays.

The trays were mounted in an attempt to provide the maximum arrival of combustion by-products while minimizing the thermal load from the plume. Since the pressure in the chamber during thruster operation is relatively high (tens of torr), it was determined that the trays needed to be as near as possible to the outer edge of the plume to provide sufficient arrival of contamination in the absence of molecular flow. The cell pressure measured during the three thruster firing sequences ranged from 10 to $\mathbf{4 0}$ torr. Two freestanding thermocouples were installed at either end of Tray \#2 in order to provide an estimate of the temperature distribution across the surface of the sample trays. Thruster firing profiles show temperatures ranging from $93^{\circ} \mathrm{C}$ to $260^{\circ} \mathrm{C}$ for the leading edge (away from diffuser) thermocouple and temperatures ranging from $177^{\circ} \mathrm{C}$ to $427^{\circ} \mathrm{C}$ for the trailing edge (near diffuser) thermocouple.

Between thruster exposures, the cell was purged to atmospheric pressure with nitrogen to allow suited personnel to enter and remove samples. The samples were placed in containers and sealed in two nitrogen purged bags. Upon removal from the cell, the samples were sealed in a third nitrogen purged bag for transportation back to NASA Lewis Research Center. Samples were stored in these purged bags in a desiccator. The purged bags were not opened to atmosphere until immediately prior to exposure to the simulated LEO environments.
Simulated LEO Environmental Exposures

\section{Exposure to a Rough Vacuum Environment}

A fused silica and a Z-93-P sample which were exposed in the PRCS thruster facility for $\mathbf{6 1 . 2}$ seconds thruster-on time were placed in a vacuum desiccator and pumped to a pressure of approximately $30 \mathrm{mtorr}$. Samples were kept in this environment for 120 hours to determine the effects of exposure to vacuum on their optical properties.

\section{Vacuum Ultraviolet (VUV) Radiation Exposure}

Samples which had been previously exposed to 91.8 seconds of PRCS thruster-on time, were exposed in the vacuum ultraviolet (VUV) exposure facility. These samples included chromic acid anodized aluminum, HEDB anodized aluminum, Z-93-P and two fused silica slides including one which was coated with approximately $1200 \dot{A}$ of silicone fluid. The VUV exposure facility contains three water-cooled copper compartments each equipped with a 30 watt deuterium lamp with a magnesium fluoride window. These compartments are located inside of a cryopumped high vacuum system bell jar which operates at a pressure of approximately $5 \times 10^{-6}$ torr. Samples are placed on the floor of these compartments. The lamps provide VUV radiation in the wavelength range between 115 and $200 \mathrm{~nm}$. The fused silica and Z-93-P samples received 312 equivalent sun hours (ESH) of VUV with an acceleration of 2.6 VUV suns, and the anodized aluminum samples received $276 \mathrm{ESH}$ of VUV with an acceleration of 2.3 VUV suns.

\section{Atomic Oxygen/Vacuum Ultraviolet Radiation Exposure}

Thruster-contaminated samples of Z-93-P and fused silica, including one fused silica sample which was also silicone contaminated, were exposed to a combined atomic oxygen/VUV radiation environment. A report by Stidham, et. al. describes this facility in detail. ${ }^{12}$ This facility uses an electron cyclotron resonance (ECR) plasma source to provide a low energy (approximately $0.04 \mathrm{eV}$ ) directed atomic oxygen beam. Deuterium lamps of the same type used in the VUV facility were used to provide VUV radiation. Effective atomic oxygen flux and fluence were measured based on the mass loss of Kapton ${ }^{*}$. Effective fluence ranged from $1.3 \times 10^{21}$ to $2.5 \times 10^{21}$ atoms $/ \mathrm{cm}^{2}$ at effective flux levels of $2.7 \times 10^{15}$ to $5.1 \times 10^{15}$ atoms $/ \mathrm{cm}^{2}$ s. VUV exposure consisted of 100 to 230 ESH at an intensity of .8 to 1.7 VUV suns. The atomic oxygen and VUV radiation were not properly 
balanced to represent the actual space environment. The simulated environment was deficient in VUV exposure in comparison with the environment to which these materials would be exposed in space.

The fused silica samples were exposed to an unknown level of additional VUV radiation at $130 \mathrm{~nm}$ from the atomic oxygen source. The Z-93-P sample was shielded from this additional VUV radiation.

The $\alpha_{s}$ of Z-93-P was characterized in situ using a reflectance measurement system from Optronic Laboratories, Inc. Samples were also characterized for $\alpha_{s} e x$ situ using the Lambda-9.

\section{Vacuum Thermal Cycling/Vacuum Ultraviolet Radiation Exposure}

Following the thruster exposures, one of the solar cells was exposed to a total of 300 vacuum thermal cycles including approximately $300 \mathrm{ESH}$ of VUV. The temperature range for thermal cycling was between $+80^{\circ} \mathrm{C}$ and $-80^{\circ} \mathrm{C}$ and the VUV intensity was approximately 5 suns between 115 and $200 \mathrm{~nm}$. Vacuum system pressure was on the order of $10^{-6}$ torr during this exposure. A report by Dever, et. al. describes this facility in detail. ${ }^{13}$

\section{RESULTS/DISCUSSION}

\section{Contamination of Samples Due to Thruster Exposure}

\section{Chemical Identification of Deposited Thruster Contaminants}

The contaminants present on a stainless steel witness coupon exposed to 91.8 seconds of thruster firing time were characterized by $\mu$-FTIR. The spectrum of this sample is shown in figure 3. This analysis indicated the presence of $\mathrm{NH}_{3}{ }^{+}$and $\mathrm{NO}_{3}{ }^{-}$ most likely indicating the presence of monomethylhydrazine nitrate (MMHN) which can be written as $\mathrm{CH}_{3} \mathrm{NHNH}_{3}{ }^{+} \mathrm{NO}_{3}^{-}$. MMHN is suspected to be the most significant contaminant from monomethylhydrazine/nitrogen tetroxide bipropellant thrusters. It has been found to be present on the walls of thruster facilities. ${ }^{1,2}$ Presence of the methyl peak, $\mathrm{CH}_{3}$ is known to be obscured by $\mathrm{NH}_{3}{ }^{+}$. Because the spectrum also shows $\mathrm{NH}_{2}$ and $\mathrm{C}=\mathrm{O}$ species, components of urea, $\mathrm{NH}_{2} \mathrm{CONH}_{2}$, it is believed that urea or urea-like compounds are also present on the sample. Urea has not been previously identified as a contaminant from thruster facilities. However, the sample trays reached high temperatures between $260^{\circ} \mathrm{C}$ and $427^{\circ} \mathrm{C}$ during thruster exposure, and this may have caused further reactions of the MMHN species leading to urea or urea-like compounds. In space, lower temperatures are expected, because the solar array and radiator surfaces would be further away from the thrusters; therefore, the chemistry may be different.

\section{Mass of Deposited Contamination}

Figure 4 shows the mass gain of stainless steel witness coupons due to accumulation of contaminants from exposure in the thruster facility during pulsed firing operations. Data points for all witness coupons and estimated errors are shown. One witness sample was installed on the sample tray during the test setup, but was removed just before the thruster firings began. The objective of this procedure was to determine whether handling or the environment in the test chamber would induce mass gain. Another sample was used as a control and was weighed with the other samples, but was not otherwise handled. The mass gains of both of these samples are shown at 0 seconds in the figure. The mass gain of the minimally handled control sample, which showed the larger weight gain, was considered to be the error in the mass measurements and was used in the calculation of the error bars for all data points. These data show that accumulation of contaminants is proportional to thruster on-time.

The amount of molecular deposition on Space Station surfaces provided by Space Shuttle thruster plumes during proximity operations is expected to be $1 \times 10^{-6} \mathrm{~g} / \mathrm{cm}^{2}$ in a year for nominal operations, according to Leger, et. al..$^{14}$ These coupons gained mass on the order of $10^{-4} \mathrm{~g} / \mathrm{cm}^{2}$. Clearly these coupons received a much greater amount of contamination than surfaces in space would receive over the lifetime of the Space Station. Therefore, the changes in optical properties due to deposition of such a large amount of contamination are expected to be worse than would actually occur in space.

\section{Effects of Deposited Contaminants on Optical Properties of Samples}

Table II shows $\alpha_{\mathrm{s}}$ and $\epsilon_{\mathrm{n}}$ values for samples before and after thruster exposure for fused silica slides, anodized aluminum samples and Z-93-P samples. Samples with initially low $\alpha_{s}$ values showed significant increases due to the contamination. The HEDB anodized aluminum sample which had the highest initial $\alpha_{s}$ showed a negligible increase. It is expected that $\epsilon_{\mathrm{n}}$ of the contaminant is between the $\epsilon_{\mathrm{n}}$ of the anodized aluminum specimens (.743 to .863 ) and the $\epsilon_{\mathrm{n}}$ of Z-93-P (.914 to .917), because the anodized aluminum samples show increases in $\epsilon_{\mathrm{n}}$, whereas the Z-93-P samples show decreases in $\epsilon_{\mathrm{n}}$.

There does not appear to be a significant correlation between $\alpha_{s}$ increase and thruster exposure 
time. This is expected to be due to significant scatter in the data.

Subsequent Simulated LEO Exposure of Contaminated Samples

\section{Exposure to Rough Vacuum}

A sample of fused silica and a sample of Z-93-P which were previously exposed to 61.2 seconds of thruster firing time were exposed in a rough vacuum of approximately 30 mtorr for 120 hours. The fused silica sample showed an increase in absorptance of 0.006 from 0.025 before exposure to 0.031 after exposure. Because the error in repeatability of the Lambda-9 instrument is considered to be approximately \pm 0.005 , this change may be within error of the instrument. The Z-93-P sample showed a reduction in $\alpha_{s}$ of 0.007 from 0.133 before exposure to 0.126 after exposure, again possibly within error of instrument repeatability. The purpose of this experiment was to determine whether dehydration of the deposited thruster contaminant would result in restoration of original optical properties and thus removal of the contaminants. These data show that dehydration of the contaminant did not cause it to completely volatilize from the sample surface. Therefore, any significant changes in optical properties of samples exposed to simulated LEO environments were not due simply to exposure to vacuum.

\section{Exposure to VUV Radiation}

Table III shows the optical properties of samples exposed to between 276 and 312 ESH of VUV radiation. Samples had previously been exposed to 91.8 seconds of thruster firing time. For solar cell materials which would be sun-facing, the 312 ESH exposure represented only approximately 18 days in space. The anodized aluminum samples were exposed to $276 \mathrm{ESH}$ which is equivalent to approximately 15 days in space. For the Z-93-P coating which would not be sun-facing, exposure to $312 \mathrm{ESH}$ represented approximately 330 days in space. The initially low solar absorptance materials, fused silica and Z-93-P, displayed increases in $\alpha_{s}$ which are outside of the error of the Lambda-9 instrument. Both the Z-93-P sample and the fused silica with silicone oil showed increases in $\alpha_{s}$ of 0.016 . This may be indicative of darkening of the contaminants on the surfaces. In space, a surface that became contaminated with thruster contaminants and/or with silicone contaminants may experience degradation in $\alpha_{\mathrm{s}}$ with subsequent or simultaneous solar ultraviolet radiation exposure. Note that the $\epsilon_{\mathrm{n}}$ values of Z-93-P and HEDB anodized aluminum changed only slightly with this exposure, whereas the chromic acid anodized aluminum showed a measurable decrease in $\epsilon_{\mathrm{n}}$. The reason for the change in this sample is not known.

\section{Exposure to Atomic Oxygen/VUV Radiation}

Table IV shows the results of exposure of samples of fused silica, fused silica with silicone oil, and Z-93$P$, all of which had previously been contaminated in the thruster facility, to atomic oxygen (AO) combined with VUV radiation. The levels of $A O$ and VUV exposure are shown as well as the ratio of AO fluence to VUV equivalent sun hours experienced in the facility to that which would be experienced on SSF for solar cells (represented by fused silica) and radiator surfaces (represented by Z-93-P). The Z-93-P coating on the photovoltaic power system radiator, which does not face the sun, would experience an atomic oxygen fluence of approximately $1.7 \times 10^{22}$ atoms $/ \mathrm{cm}^{2}$ and 5,160 hours of solar ultraviolet radiation in 15 years. ${ }^{15}$ The solar array surfaces would experience an atomic oxygen fluence of $4.3 \times 10^{22}$ atoms $/ \mathrm{cm}^{2}$ and up to approximately 97,500 hours of solar ultraviolet radiation in 15 years. ${ }^{16,17}$ The ratio of (AO/VUV) Test to $(\mathrm{AO} / \mathrm{VUV})_{\mathrm{SS}}$ indicates the imbalance in the ratio of AO fluence to VUV equivalent sun hours experienced by the test coupons as compared to space. Note that the AO dose in this test was excessive in comparison with the VUV dose in the test for comparison to the Space Station environments. The fused silica materials experienced more of an excess of AO than the Z-93-P as indicated by the fact that the ratio was much greater for the fused silica samples.

Values of $\alpha_{s}$ for all of the fused silica samples decreased, probably indicating that atomic oxygen reacted with the contaminants on the surface and oxidized and removed some of them. The AO/VUV exposure did significantly reduce $\alpha_{s}$, although it did not restore the original $\alpha_{s}$ values measured prior to contamination in the thruster facility. For solar cells which contain coverglass, these data imply that contamination may not severely compromise performance as long as the cells are in an atomic oxygen environment. However, caution must be used in interpreting these results because the test environment contained a much greater $\mathrm{AO}$ dose in comparison to the VUV than would occur in space.

The in situ measurements of Z-93-P show an increase in $\alpha_{s}$ of 0.03 . This is probably more indicative of VUV-induced color center formation in the pigment of Z-93-P than of a synergistic reaction of the AO/VUV environment to darken the contaminants. This type of color center formation is reversible by oxidation and such reversal would occur upon bringing the sample from vacuum to atmosphere. The ex situ measurements of Z-93-P 
indicate a reduction in $\alpha_{\mathrm{s}}$. Because the sample was removed from vacuum, color centers that formed during exposure were likely eliminated, and the reduction in $\alpha_{s}$ likely indicates oxidation and removal of contamination similar to that for the fused silica samples.

Note that the pre-exposure in situ and ex situ $\alpha_{s}$ values are different. There are two contributors to this difference. First, recall that exposure of a Z-93-P sample in a rough vacuum caused a 0.007 reduction in $\alpha_{s}$. Second, it is likely that there is a difference in accuracy between the two instruments. Both instruments have good repeatability, and, because the purpose of these investigations was to determine changes in $\alpha_{s}$ due to exposure to the AO/VUV environment, attempts were not made at this time to correlate the two instruments.

\section{$\underline{\text { Solar Cell Performance }}$}

Figure 5 shows changes in solar cell efficiency as a function of the various treatments for two cells labeled SC-1 and SC-3. The efficiency is the ratio of the power input from the solar simulator to the measured power output of the cell. Error bars are indicated. Note that exposure to $\mathrm{Al}_{2} \mathrm{O}_{3}$ and the thruster contaminants resulted in some performance degradation. Exposure to the first $150 \mathrm{VUV} /$ thermal cycles indicated continued degradation. After exposure to another 150 cycles, for a total of 300 VUV/thermal cycles, a slight improvement was observed. However, the measured cell efficiencies after VUV/thermal cycling may be within error of the measured cell efficiency prior to this exposure.

Therefore, the indicated changes due to VUV/thermal cycling may not be significant. One may conclude that exposure of solar cells to an environment containing temperature cycling and solar ultraviolet radiation would probably not improve cell efficiency, but may not further the degradation. Because of the facility limitations, only one cell was able to be tested in this manner. Additional tests would allow statistical correlations to be made.

Based on the effect of AO/VUV exposure on the fused silica samples, which was to decrease $\alpha_{s}$, it is likely that an environment containing atomic oxygen and solar ultraviolet radiation would restore some of the efficiency of the contaminated cells.

\section{CONCLUSIONS}

Contamination of fused silica slides and thermal control surfaces exposed to a Space Shuttle type thruster in a vacuum facility resulted in significant $\alpha_{s}$ increases. This performance loss appears to be reversed to a great extent by subsequent exposure to combined atomic oxygen/VUV radiation, most likely due to the atomic oxygen component of this environment. This may indicate that the natural onorbit environment provides "cleaning" of the bipropellant thruster-induced contamination, as long as atomic oxygen is part of this environment. Degradation observed for the Z-93-P coating in the atomic oxygen/VUV environment, based on in situ measurements, is probably caused by VUV radiation effects on the pigment rather than darkening of contamination. The VUV radiation environment alone caused some degradation of previously contaminated anodized aluminum, Z-93-P and fused silica. This implies that solar ultraviolet radiation can react with deposited thruster contaminants resulting in a darkened film.

Contamination with aluminum oxide and thruster contaminants reduced the efficiency of solar cells. Subsequent thermal cycling combined with VUV radiation exposure did not result in continued degradation. Also, results from the atomic oxygen/VUV exposure of fused silica would indicate that atomic oxygen exposure of contaminated cells would likely result in some restoration of cell efficiency.

\section{ACKNOWLEDGEMENTS}

The authors would like to acknowledge the technical support of the following: Sharon $\mathrm{K}$. Rutledge, Kim K. de Groh and Dr. Marla E. PerezDavis of the Electro-Physics Branch at NASA Lewis Research Center; Bryan K. Smith and Marian C. Felder of the Solar Array Branch at NASA Lewis Research Center; Robert Cort of NASA Johnson Space Center/White Sands Test Facility; Gerald F. Winans of Lockheed Engineering \& Sciences Co. supporting White Sands Test Facility; Dr. Pilar C. Herrera-Fierro of Case Western Reserve University supporting the NASA LeRC Surface Science Branch; Daniel A. Scheiman of NYMA, Inc. supporting the NASA LeRC Polymers Branch; Tim McCollum and Ed Sechkar of Cleveland State University; personnel from Illinois Institute of Technology Research Institute; and personnel from the Space Station Division of McDonnell Douglas Aerospace, especially Cherie A. Jones and Huong G. Le.

\section{REFERENCES}

1. Etheridge, F. G. and Boudreaux, R. A., "AttitudeControl Rocket Exhaust Plume Effect on Spacecraft Functional Surfaces," Journal of Spacecraft and Rockets, Vol. 7, Jan. 1970, pp. 44 48. 
2. Takimoto, H. H. and Denault, G. D., "Rocket Plume $\left(\mathrm{N}_{2} \mathrm{O}_{4} / \mathrm{MMH}\right)$ Impingement on Aluminum Surface," Journal of Spacecraft and Rockets, Vol. 7, Nov. 1970, pp. 1372-1374.

3. Jack, J. R., Spisz, E. W. and Cassidy, J. F., "The Effect of Rocket Plume Contamination on the Optical Properties of Transmitting and Reflecting Materials," American Institute of Aeronautics and Astronautics Paper No. 72-56, January 1972.

4. Bowman, R. L., Spisz, E. W. and Jack, J. R., "Effect of Contamination on the Optical Properties of Transmitting and Reflecting Materials Exposed to a $\mathrm{MMH} / \mathrm{N}_{2} \mathrm{O}_{2}$ Rocket Exhaust," NASA Technical Memorandum X-68204, April, 1973.

5. Liu, C. and Glassford, A. P. M., "Contamination Effect of $\mathrm{MMH} / \mathrm{N}_{2} \mathrm{O}_{2}$ Rocket Plume Product Deposit, Journal of Spacecraft and Rockets, Volume 18, No. 4, August 1981, pp. 306-11.

6. Koontz, S., et. al., "Shuttle Primary Reaction Control System (PRCS) Engine Exhaust Plume Contamination Effects: The Shuttle Plume Impingement Experiment (SPIE), STS-52," American Institute of Aeronautics and Astronautics Paper No. 93-0618, January 1993.

7. Tribble, A. C., "Low Earth Orbit Plasma Effects on Spacecraft," American Institute of Aeronautics and Astronautics Paper No. 93-0614, January 1993.

8. Banks, B. A., et. al., "Atomic Oxygen Interactions with FEP Teflon and Silicones on LDEF," in LDEF - 69 Months in Space. First Post-Retrieval Symposium, NASA Conference Publication 3134, Part 2, June 1991.

9. Stewart, T. B., Arnold, G. S., Hall, D. F., and Marten, H. D., "Photolysis of Spacecraft Contaminants," The Aerospace Corporation Report SD-TR-89-45, July 1989.

10. Stewart, T. B. et. al., "Photochemical Spacecraft Self-Contamination: Laboratory Results and Systems Impacts," The Aerospace Corporation Report TOR-0090 (5470-01)-3, July 1990.

11. Seiber, B. L., Bertrand, W. T. and Wood, B. E., "Contamination Effects of Satellite Material Outgassing Products on Thermal Surfaces and Solar Cells," Arnold Engineering Development Center Report AEDC-TR-90-27, December 1990.
12. Stidham, C. R. et. al., "Low Earth Orbital Atomic Oxygen Environmental Simulation Facility for Space Materials Evaluation," in Bailey, V. et. al., eds., Proceedings of the 38th International SAMPE Symposium and Exhibition, Advanced Materials: Performance Through Technology Insertion, Science of Advanced Materials and Process Engineering Series, Volume 38, Book 1, 1993, Society for the Advancement of Material and Process Engineering, Covina, CA., 1993, pp. 64963.

13. Dever, J. A., et. al., "Simulation of the Synergistic Low Earth Orbit Effects of Vacuum Thermal Cycling, Vacuum UV Radiation and Atomic Oxygen," in NASA Conference Publication 3181, Proceedings of the 17th Space Simulation Conference, Terrestrial Test for Space Success, NASA, Greenbelt, MD, 1992, pp. 19-36.

14. Leger, L., et. al., "External Induced Contamination Environment Assessment for Space Station Freedom," American Institute of Aeronautics and Astronautics Paper No. 93-0617, January 1993.

15. Booth, R. E., "PVR Thermal Control Coating Test Plan," LTV DIR No. 3-47300/IDIR-037, August 1991.

16. Jones, C. A., Personal Communication, McDonnell Douglas Aeronautics, March 22, 1994.

17. Specification Number RC1800, Revision C, Rockwell International Corporation, Rocketdyne Division, Canoga Park, CA, January 11, 1990, p. 18. 
TABLE I - Contents of Sample Trays for Thruster Exposure

\begin{tabular}{|c|c|c|c|}
\hline $\begin{array}{l}\text { Tray } \\
\text { No. }\end{array}$ & Samples & Qty. & Size \\
\hline \multirow[t]{3}{*}{1} & fused silica & 12 & $2.5 \mathrm{~cm} \mathrm{dia.}$ \\
\hline & silicone-contaminated fused silica & 4 & $2.5 \mathrm{~cm} \mathrm{dia.}$ \\
\hline & stainless steel witnesses & 3 & $2.5 \mathrm{~cm}$ dia. \\
\hline \multirow[t]{5}{*}{2} & fused silica & 3 & $2.5 \mathrm{~cm}$ dia. \\
\hline & silicone-contaminated fused silica & 1 & $2.5 \mathrm{~cm} \mathrm{dia.}$ \\
\hline & Z-93-P on aluminum & 6 & $2.5 \mathrm{~cm}$ dia. \\
\hline & anodized aluminum & 3 & $2.5 \mathrm{~cm} \mathrm{x} 2.5 \mathrm{~cm}$ \\
\hline & stainless steel witnesses & 3 & $2.5 \mathrm{~cm}$ dia. \\
\hline \multirow[t]{2}{*}{3} & solar cells & 2 & $8 \mathrm{~cm} \times 8 \mathrm{~cm}$ \\
\hline & stainless steel witnesses & 2 & $2.5 \mathrm{~cm}$ dia. \\
\hline
\end{tabular}

TABLE II - Effects of Thruster Contaminants on Optical Properties

\begin{tabular}{|c|c|c|c|c|c|c|}
\hline \multirow{3}{*}{$\begin{array}{l}\text { Sample } \\
\text { Type }\end{array}$} & \multirow{3}{*}{$\begin{array}{l}\text { Tray } \\
\text { No. }\end{array}$} & \multirow{3}{*}{$\begin{array}{c}\text { Thruster } \\
\text { On-time } \\
\text { (s) }\end{array}$} & \multicolumn{4}{|c|}{ Thruster On-Time } \\
\hline & & & \multicolumn{2}{|c|}{ Pre-Exposure } & \multicolumn{2}{|c|}{ Post-Exposure } \\
\hline & & & $\alpha_{s}$ & $\epsilon_{\mathrm{n}}$ & $\alpha_{\mathrm{s}}$ & $\epsilon_{\mathrm{n}}$ \\
\hline \multirow[t]{2}{*}{ Fused silica } & \multirow{3}{*}{1} & 30.6 & -.003 & - & .078 & - \\
\hline & & 61.2 & -.003 & -- & .058 & -- \\
\hline Fused silica with silicone oil & & 91.8 & .002 & - & .045 & -- \\
\hline Chromic acid anodized $\mathrm{Al}$ & \multirow{9}{*}{2} & 91.8 & .493 & .743 & .516 & .798 \\
\hline Sulfuric acid anodized $\mathrm{Al}$ & & 91.8 & .461 & .863 & .490 & .884 \\
\hline HEDB anodized Al & & 91.8 & .857 & .859 & .855 & .866 \\
\hline \multirow[t]{6}{*}{ Z-93-P } & & 61.2 & .097 & -- & .122 & - \\
\hline & & 61.2 & .101 & -- & .183 & -- \\
\hline & & 61.2 & -- & .917 & - & .908 \\
\hline & & 91.8 & - & .916 & - & .910 \\
\hline & & 91.8 & .102 & .915 & .135 & .910 \\
\hline & & 91.8 & .105 & .914 & .162 & .908 \\
\hline
\end{tabular}


TABLE III - Vacuum Ultraviolet Radiation Effects on Optical Properties of Contaminated Samples

\begin{tabular}{|c|c|c|c|c|c|c|}
\hline \multirow{3}{*}{$\begin{array}{l}\text { Sample } \\
\text { Type }\end{array}$} & \multirow{3}{*}{$\begin{array}{l}\text { Tray } \\
\text { No. }\end{array}$} & \multirow{3}{*}{$\begin{array}{l}\text { ESH VUV } \\
\text { @ no. of } \\
\text { suns }\end{array}$} & \multicolumn{4}{|c|}{ Optical properties } \\
\hline & & & \multicolumn{2}{|c|}{ Before VUV } & \multicolumn{2}{|c|}{ After VUV } \\
\hline & & & $\alpha_{s}$ & $\epsilon_{\mathrm{n}}$ & $\alpha_{s}$ & $\epsilon_{\mathrm{n}}$ \\
\hline Fused silica & \multirow[t]{2}{*}{1} & \multirow[t]{3}{*}{$312 @ 2.6$} & .027 & -- & .038 & -- \\
\hline $\begin{array}{l}\text { Fused silica } \\
\text { with silicone } \\
\text { oil }\end{array}$ & & & .020 & -- & .036 & -- \\
\hline Z-93-P & 2 & & .141 & .910 & .157 & .912 \\
\hline $\begin{array}{l}\text { Chromic acid } \\
\text { anodized } \mathrm{Al}\end{array}$ & \multirow[t]{2}{*}{2} & \multirow[t]{2}{*}{$276 @ 2.3$} & .550 & .798 & .558 & .786 \\
\hline $\begin{array}{c}\text { HEDB } \\
\text { anodized Al }\end{array}$ & & & .856 & .866 & .848 & .867 \\
\hline
\end{tabular}

TABLE IV - AO/VUV Exposure Effects on Solar Absorptance of Contaminated Samples

\begin{tabular}{|c|c|c|c|c|c|c|}
\hline \multirow{2}{*}{$\begin{array}{c}\text { Sample } \\
\text { Type }\end{array}$} & \multirow{2}{*}{$\begin{array}{c}\text { Thruster } \\
\text { Exposure (firing } \\
\text { time, s) }\end{array}$} & \multirow{2}{*}{$\begin{array}{c}\text { Effective AO } \\
\text { Fluence } \\
\left(\text { at } / \mathrm{cm}^{2}\right) \\
\text { @ Flux } \\
\text { (at/cms) }\end{array}$} & \multirow{2}{*}{$\begin{array}{c}\text { ESH VUV } \\
\text { @ no. of } \\
\text { suns }\end{array}$} & \multirow{2}{*}{$\frac{(A O / V U V)_{\text {Test }}}{(A O / V U V)_{S s}}$} & \multicolumn{2}{|c|}{ Solar Absorptance } \\
\hline & & & & & $\begin{array}{c}\text { Before } \\
\text { Exposure }\end{array}$ & $\begin{array}{c}\text { After } \\
\text { Exposure }\end{array}$ \\
\hline Fused silica & 30.6 & $\begin{array}{c}2.6 \times 10^{21} \\
@ 5.1 \times 10^{15}\end{array}$ & $\begin{array}{c}105 \\
@ .79\end{array}$ & 49 & .078 & .008 \\
\hline $\begin{array}{l}\text { Fused silica } \\
\text { with } \\
\text { silicone oil }\end{array}$ & 91.8 & $\begin{array}{c}2.0 \times 10^{21} \\
@ 4.1 \times 10^{15}\end{array}$ & $\begin{array}{c}147 \\
@ 1.1\end{array}$ & 27 & .045 & .021 \\
\hline Fused silica & 61.2 & & & & .058 & .015 \\
\hline \multirow[t]{4}{*}{ Z-93-P } & \multirow[t]{4}{*}{61.2} & \multirow{2}{*}{$\begin{array}{c}6.8 \times 10^{20} \\
@ 3.0 \times 10^{15}\end{array}$} & \multirow{2}{*}{$\begin{array}{c}103 \\
@ 1.7\end{array}$} & \multirow[t]{2}{*}{3.1} & \multicolumn{2}{|c|}{ In situ: } \\
\hline & & & & & .167 & .196 \\
\hline & & \multirow{2}{*}{$\begin{array}{c}1.3 \times 10^{21} \\
@ 2.7 \times 10^{15}\end{array}$} & \multirow{2}{*}{$\begin{array}{c}226 \\
@ 1.7\end{array}$} & \multirow[t]{2}{*}{2.7} & \multicolumn{2}{|c|}{ Ex situ: } \\
\hline & & & & & .183 & .122 \\
\hline
\end{tabular}




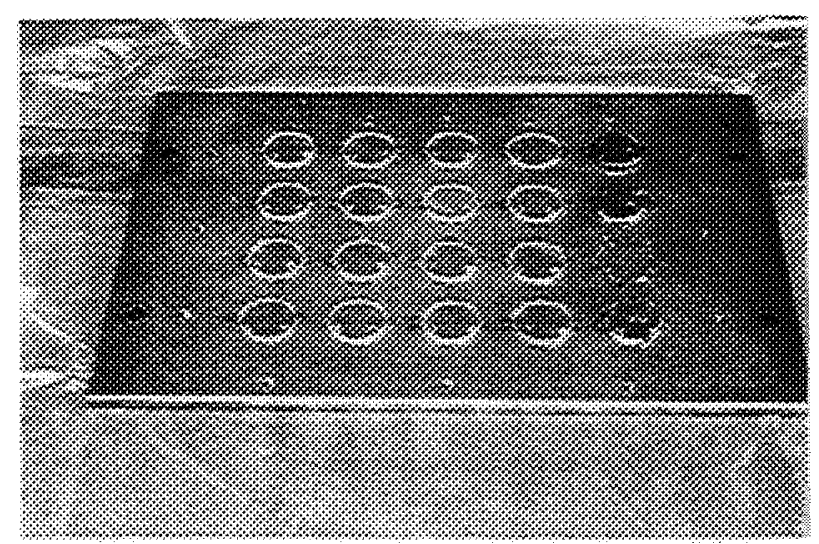

(a)

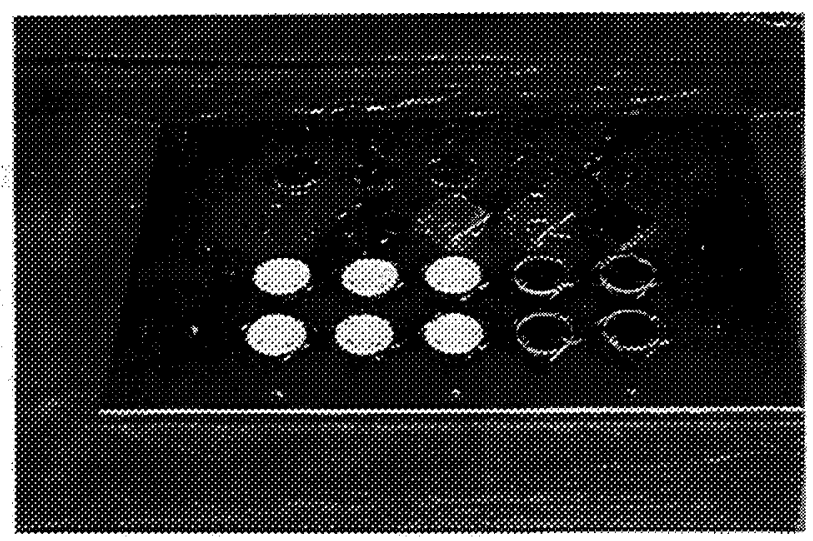

(b)

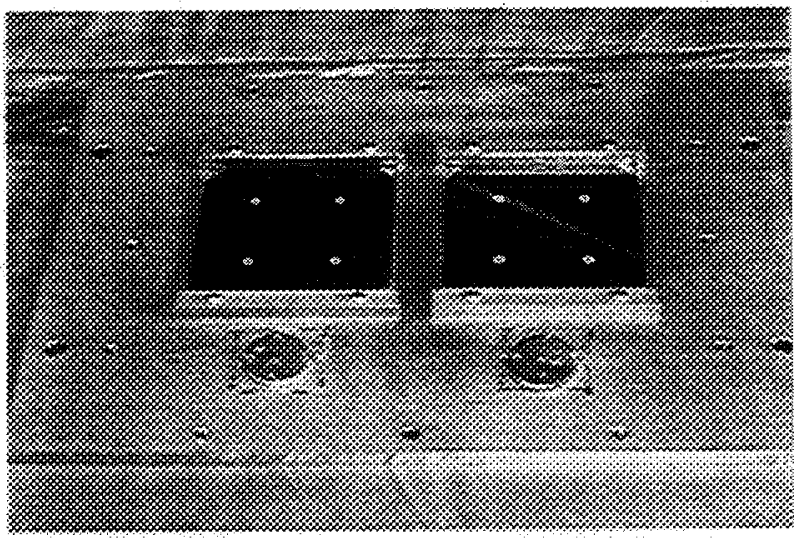

(c)

Figure 1: Sample trays for thruster fuel contamination: (a) Tray 1, (b) Tray 2, and (c) Tray 3.

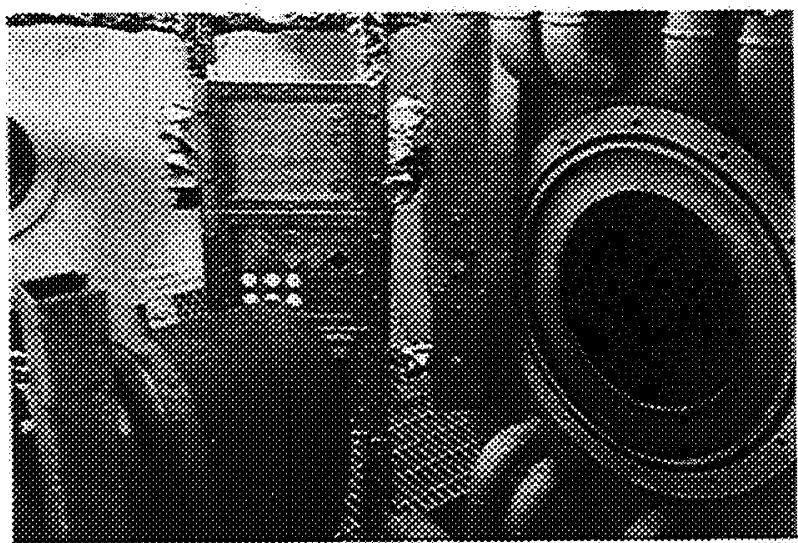

(a)

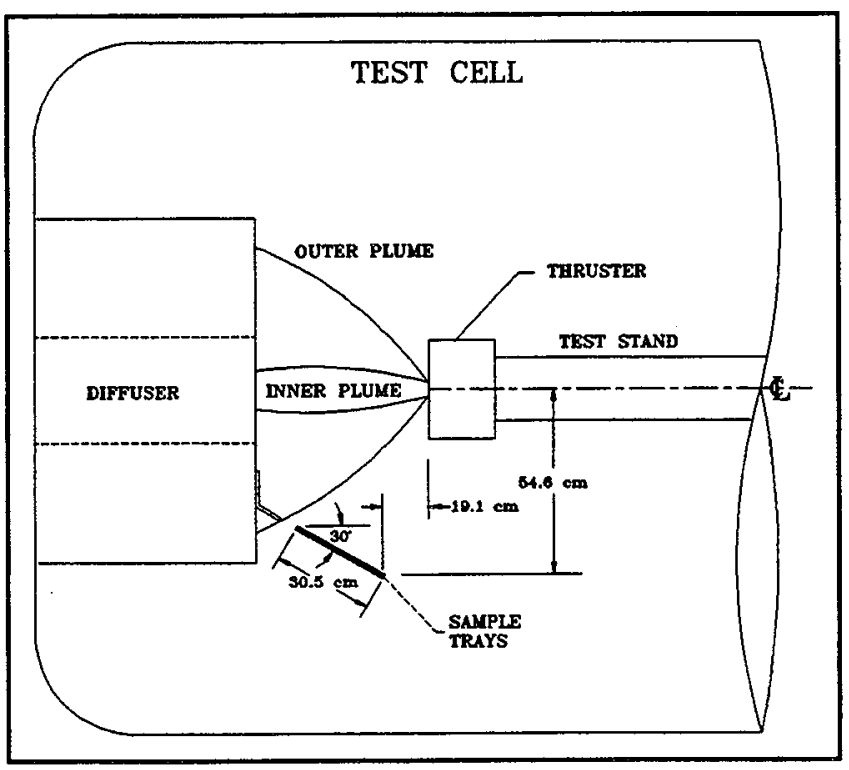

(b)

Figure 2: Configuration of sample trays with respect to thruster: (a) photograph of facility and (b) top view drawing of test cell. 


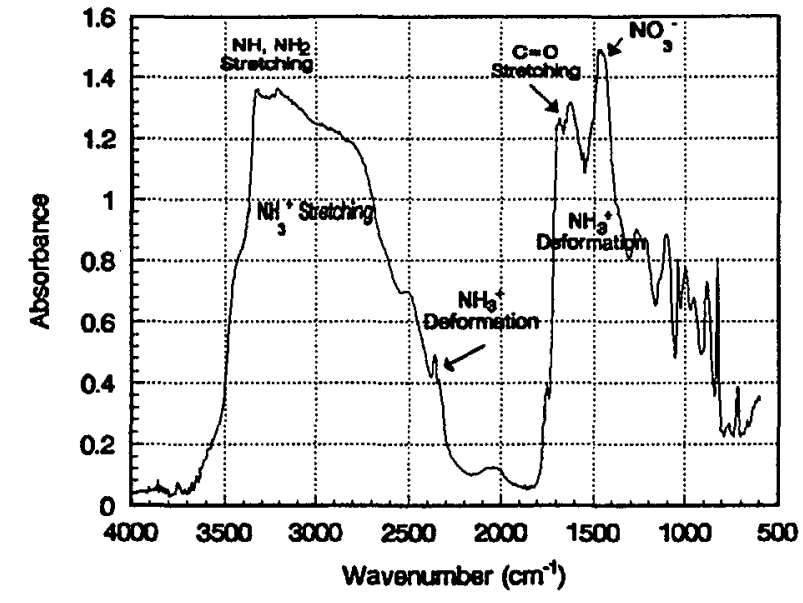

Figure 3: $\quad \mu$-FTIR spectrum of contaminants analyzed on stainless steel sample.

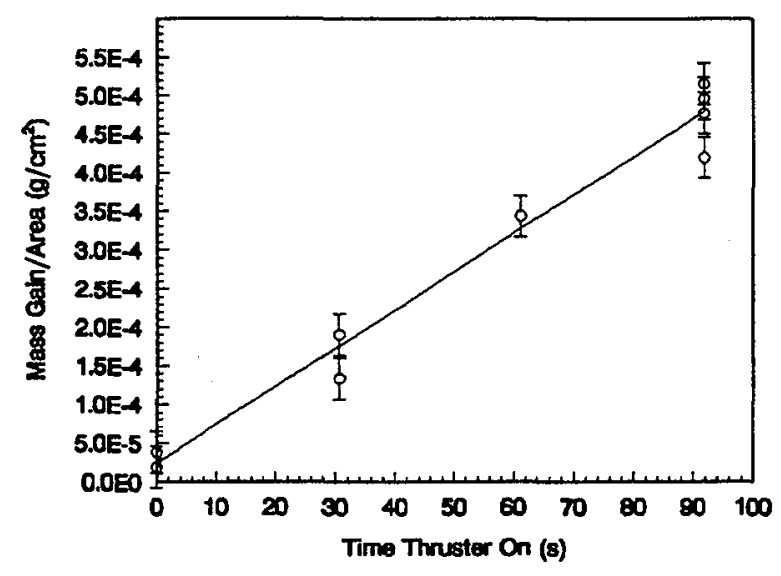

Figure 4: $\quad$ Mass gain of thruster-exposed stainless steel samples.

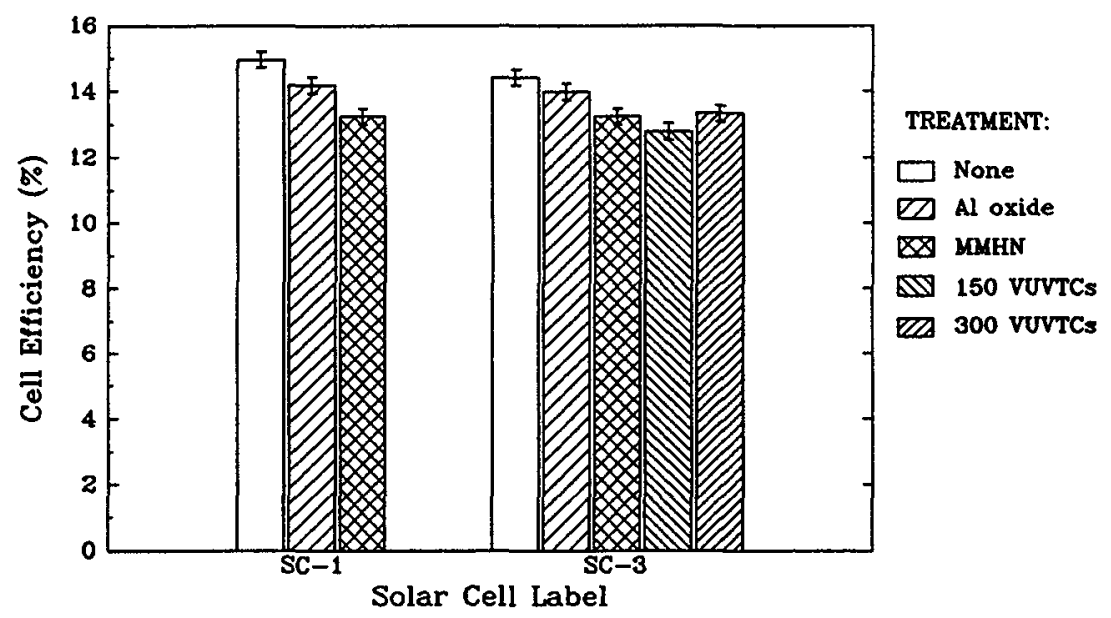

Figure 5: $\quad$ Combined contamination/simulated LEO environmental effects on solar cell efficiency. 
Public reporting burden for this collection of information is estimated to average 1 hour per response, including the time for reviewing instructions, searching existing data sources. gathering and maintaining the data needed, and completing and reviewing the collection of information. Send comments regarding this burden estimate or any other aspect of this collection of information, including suggestions for reducing this burcen, to Washington Headquarters Services, Directorate for Information Operations and Reports, 1215 Jefferson Davis Highway, Suite 1204, Arlington, VA 22202-4302, and to the Office of Management and Budget, Paperwork Reduction Project (0704-0188), Washington, DC 20503.

\begin{tabular}{|l|l|l|}
\hline 1. AGENCY USE ONLY (Leave blank) & $\begin{array}{c}\text { 2. REPORT DATE } \\
\text { May } 1994\end{array}$ & $\begin{array}{r}\text { 3. REPORT TYPE AND DATES COVERED } \\
\text { Technical Memorandum }\end{array}$ \\
\hline
\end{tabular}

4. TITLE AND SUBTITLE

Combined Contamination and Space Environmental Effects on

Solar Cells and Thermal Control Surfaces

6. AUTHOR(S)

Joyce A. Dever, Eric J. Bruckner, David A. Scheiman, and Curtis R. Stidham

\section{FUNDING NUMBERS}

WU-474-46-10
7. PERFORMING ORGANIZATION NAME(S) AND ADDRESS(ES)

National Aeronautics and Space Administration

Lewis Research Center

Cleveland, Ohio 44135-3191

9. SPONSORING/MONITORING AGENCY NAME(S) AND ADDRESS(ES)

National Aeronautics and Space Administration

Washington, D.C. 20546-0001
8. PERFORMING ORGANIZATION REPORT NUMBER

E-8859

10. SPONSORING/MONITORING AGENCY REPORT NUMBER

NASA TM-106592

AIAA 94-2627

11. SUPPLEMENTARY NOTES

Prepared for the 18th AIAA Aerospace Ground Testing Conference sponsored by the American Institute of Aeronautics and Astronautics, Colorado Springs, Colorado, June 20-23, 1994. Joyce A. Dever, NASA Lewis Research Center; David A. Scheiman and Curtis R. Stidham, NYMA, Inc., Engineering Services Division, 2001 Aerospace Parkway, Brook Park, Ohio 44142 (work funded by NASA Contract NAS3-27186); and Eric J. Bruckner, Cleveland State University, Cleveland, Ohio 44115. Responsible person, Joyce A. Dever, organization code 5480, (216) 433-6294.

\begin{tabular}{|l|l}
\hline 12a. DISTRIBUTIONAVAILABILITY STATEMENT & 12b. DISTRIBUTION CODE
\end{tabular}

Unclassified - Unlimited

Subject Categories 23 and 28

13. ABSTRACT (Maximum 200 words)

For spacecraft in low Earth orbit (LEO), contamination can occur from thruster fuel, sputter contamination products and from products of silicone degradation. This paper describes laboratory testing in which solar cell materials and thermal control surfaces were exposed to simulated spacecraft environmental effects including contamination, atomic oxygen, ultraviolet radiation and thermal cycling. The objective of these experiments was to determine how the interaction of the natural LEO environmental effects with contaminated spacecraft surfaces impacts the performance of these materials. Optical properties of samples were measured and solar cell performance data was obtained. In general, exposure to contamination by thruster fuel resulted in degradation of solar absorptance for fused silica and various thermal control surfaces and degradation of solar cell performance. Fused silica samples which were subsequently exposed to an atomic oxygen/vacuum ultraviolet radiation environment showed reversal of this degradation. These results imply that solar cells and thermal control surfaces which are susceptible to thruster fuel contamination and which also receive atomic oxygen exposure may not undergo significant performance degradation. Materials which were exposed to only vacuum ultraviolet radiation subsequent to contamination showed, slight additional degradation in solar absorptance.

14. SUBJECT TERMS

15. NUMBER OF PAGES

Low Earth orbit; Thruster fuel; Contamination; Thermal control coatings; Solar cells 13

16. PRICE CODE

$\mathrm{A} 03$

17. SECURITY CLASSIFICATION
OF REPORT
Unclassified

NSN 7540-01-280-5500
18. SECURITY CLASSIFICATION OF THIS PAGE Unclassified
19. SECURITY CLASSIFICATION OF ABSTRACT Unclassified

\section{LIMITATION OF ABSTRACT

20. LIMITATION OF ABSTRACT

